\title{
ANALISIS POTENSI EKONOMI PETERNAK SAPI PERAH TERHADAP PEMBANGUNAN EKONOMI HIJAU DI KABUPATEN PASURUAN
}

\section{Analysis Of The Economic Potential Of Dairy Cattle Farmers On Green Economic Development In Pasuruan District}

\author{
Bambang Sutikno'), Jati Batoro ${ }^{2)}$ \\ ${ }^{1}$ Mahasiswa Program Doktor Ilmu Lingkungan Universitas Brawijaya \\ ${ }^{2}$ Staf Pengajar Program Doktor Ilmu Lingkungan Universitas Brawijaya \\ Email: bambangsutikno@gmail.com
}

\begin{abstract}
ABSTRAK
Potensi ekonomi peternak sapi perah merupakan faktor yang sangat penting untuk diperhatikan dalam pembangunan ekonomi hijau. Tujuan penelitian ini adalah menganalisis hubungan antara potensi ekonomi peternak sapi perah terhadap pembangunan ekonomi hijau di Kabupaten Pasuruan. Jenis penelitian ini adalah explanatory research yaitu menguji hipotesis penelitian. Populasi penelitian adalah peternak sapi perah di Kabupaten Pasuruan. Sampel penelitian ini peternak sapi perah di tiga kecamatan di Kabupaten Pasuruan. Penarikan sampel dengan menggunakan stratifikasi random sampling. Teknik analisa data yang digunakan adalah analisis regresi linier berganda dengan melakukan uji t. Hasil penelitian menunjukkan potensi ekonomi peternak sapi perah memberikan pengaruh yang signifikan sebesar 2,657 terhadap pembangunan ekonomi hijau di Kabupaten Pasuruan.

Kata Kunci : potensi ekonomi, pembangunan ekonomi hijau
\end{abstract}

\begin{abstract}
The economic potential of dairy farmers is a very important factor to consider in the development of a green economy. The purpose of this study was to analyze the relationship between the economic potential of dairy farmers for green economy development in Pasuruan Regency. This type of research is explanatory research, namely testing the research hypothesis. The study population was dairy farmers in Pasuruan Regency. The research sample is dairy farmers in three sub-districts in Pasuruan Regency. Sampling using stratification random sampling. The data analysis technique used is multiple linear regression analysis by conducting the $t$ test. The results showed that the economic potential of dairy farmers gave a significant influence of 2,657 on green economy development in Pasuruan Regency.
\end{abstract}

Keywords: economic potential, green economy development

\section{PENDAHULUAN}

Peternak sapi perah dalam suatu kawasan sangat bergantung pada keberadaan kelembagaan koperasi susu sebagai lembaga yang memfasilitasi kegiatan usaha peternak. Peternak sebagai anggota koperasi dalam mengembangkan kawasan sapi perah perlu difasilitasi, terutama dalam penguatan perencanaan, penguatan kerja sama dan kemitraan, penguatan sarana dan prasarana, penguatan sumber daya manusia, 
penguatan kelembagaan, percepatan adopsi teknologi serta pengembangan industri hilir.

Kabupaten Pasuruan memiliki potensi ekonomi yang berlimpah berupa populasi sapi perah lebih tinggi dibandingkan dengan Kota Batu. Penetapan kawasan pengembangan sapi perah menjadi penting terkait dengan perencanaan pembangunan industri susu nasional, mulai dari penyediaan prasarana, sarana penunjang, teknologi, pembiayaan, pengolahan, pemasaran serta kelembagaan dan sumber daya manusia. Industri susu nasional merupakan industri strategis yang potensial, karena permintaan yang terus meningkat seiring dengan kenaikan taraf hidup masyarakat. Manajemen koperasi sangat menentukan efektivitas mekanisme perkembangan industri persusuan nasional (Priyono dan Priyanti, 2015).

Potensi ekonomi peternak sapi perah di Kabupaten Pasuruan didukung dengan adanya koperasi susu yang cukup besar yang berjumlah empat. KUTT Suka Makmur yang ada di Kecamatan Grati Kabupaten Pasuruan dengan produksi 58 ton susu per hari dengan jumlah 4.000 peternak. Koperasi Susu sembada di Kecamatan Puspo Kabupaten Pasuruan dengan produksi susu 18 ton per hari dengan jumlah 7.425 peternak. KPSP
Setia Kawan Nongkojajar di kecamatan Tutur Kabupaten Pasuruan dengan produksi susu 71 ton per hari dengan jumlah 8.125 peternak. KUD Dadi Jaya yang ada di Kecamatan Purwodadi Kabupaten Pasuruan dengan produksi 26 ton per hari dengan 5.570 peternak (BPS, 2013). Produk olahan susu saat ini masih berupa minuman sebagai produk home industry di daerah Nongkojajar.

Potensi ekonomi merupakan factor yang penting yang perlu diperhatikan dalam pembangunan ekonomi hijau. Pernyataan ini sejalan dengan hasil temuan Sutikno dan Batoro (2016) yang menyatakan bahwa variabel potensi ekonomi berpengaruh signifikan dengan peran koperasi susu dan peran koperasi susu berpengaruh signifikan terhadap variabel pembangunan masyarakat lokal dengan indikator ekonomi hijau. Woolcock dan Narayan (2000) menyatakan bahwa model sosial disesuaikan untuk menunjukkan potensi pengembangan usaha dan mengontrol takdir sosial ekonomi masyarakat. Green dan Mccann (2011) menemukan lima isu utama dalam penerapan ekonomi hijau antara lain, dampak organisasi dan budaya, mengembangkan kepemimpinan yang tepat, penciptaan lapangan, teknologi untuk menciptakan lapangan kerja dan 
mempertahankan kualitas hidup peternak sapi perah di Kabupaten masyarakat membawa konsekuensi yang Pasuruan. Sampel penelitian ini sebesar 80 tidak diinginkan, serta kepemimpinan peternak sapi perah di tiga kecamatan di dalam ekonomi hijau. Caprotti dan Bailey Kabupaten Pasuruan. Penarikan sampel (2014) menguraikan berbagai isu penting dengan menggunakan stratifikasi random tentang ekonomi hijau yang khususnya sampling. Variable yang digunakan ada terkait dengan analisis geografis. Pertama dua yaitu, potensi ekonomi peternak sapi menyangkut pertanyaan sekitar perah dan pembangunan ekonomi hijau. pembangunan ekonomi hijau, transisi Teknik analisa data yang digunakan ekonomi, sementara yang ketiga adalah analisis regresi linier berganda membahas kebutuhan kritis penilaian dari dengan melakukan uji t. logika dan mekanisme pemerintahan dan transisi yang melihat ekonomi hijau sebagai mekanisme kunci untuk ekonomi, perubahan sosial dan lingkungan. Oleh karena itu perlu dilakukan penelitian tentang analisis hubungan antara potensi ekonomi peternak sapi perah terhadap pembangunan ekonomi hijau di Kabupaten Pasuruan.

\section{METODE PENELITIAN}

Penelitian ini adalah explanatory research yaitu menguji hipotesis penelitian. Populasi penelitian adalah ekonomi hijau.

\section{HASIL DAN PEMBAHASAN}

\section{Hasil}

Hasil analisis uji hipotesa menggunakan uji $\mathrm{t}$ yang diperlihatkan pada Tabel 1. Tabel 1 memperlihatkan bahwa dari variabel peran koperasi diperoleh nilai probabilitas (sig) $0,023<$ 0,05 dan nilai $t_{\text {hitung }}>t_{\text {tabel }}(2,657>1,994)$ maka $\mathrm{H}_{0}$ ditolak dan $\mathrm{H}_{1}$ diterima, artinya ada pengaruh yang signifikan dari variabel bebas, yaitu potensi ekonomi peternak sapi perah terhadap pembangunan

\section{Tabel 1. Hasil Uji t}

Coefficients $^{\mathrm{a}}$

\begin{tabular}{|c|c|c|c|c|c|c|}
\hline & \multirow{2}{*}{ Model } & \multicolumn{2}{|c|}{$\begin{array}{c}\text { Unstandardized } \\
\text { Coefficients }\end{array}$} & \multirow{2}{*}{$\begin{array}{c}\text { Standardized } \\
\text { Coefficients } \\
\text { Beta }\end{array}$} & \multirow{2}{*}{$\mathrm{t}$} & \multirow{2}{*}{ Sig. } \\
\hline & & B & $\begin{array}{c}\text { Std. } \\
\text { Error }\end{array}$ & & & \\
\hline \multirow[t]{2}{*}{1} & (Constant) & 3.159 & .340 & & 9.297 & .000 \\
\hline & Potensi Ekonomi & .176 & .100 & .195 & 2.657 & .023 \\
\hline
\end{tabular}




\section{Pembahasan}

Hasil analisis uji t diperoleh bahwa pengaruh memperlihatkan bahwa potensi ekonomi peternak sapi perah terhadap pembangunan ekonomi hijau sebesar 2,757 dengan Sig 0,023 yang artinya ada pengaruh yang signifikan dari variabel bebas, yaitu potensi ekonomi peternak sapi perah terhadap pembangunan ekonomi hijau. Hal ini menunjukkan bahwa potensi ekonomi peternak sapi perah merupakan faktor yang menentukan pembangunan ekonomi hijau di Kabupaten Pasuruan. Temuan penelitian ini sejalan dengan temuan penelitian yang dilakukan Potensi ekonomi merupakan factor yang penting yang perlu diperhatikan dalam pembangunan ekonomi hijau. Pernyataan ini sejalan dengan hasil temuan Sutikno dan Batoro (2016) yang menyatakan bahwa variabel potensi ekonomi berpengaruh signifikan dengan peran koperasi susu dan peran koperasi susu berpengaruh signifikan terhadap variabel pembangunan masyarakat lokal dengan indicator ekonomi hijau.

Potensi ekonomi juga dapat ditingkatkan melalui pembangunan ekonomi hijau. Pernyataan ini sejalan dengan temuan Babonea dan Joia (2012) yang menyatakan green economy

merupakan salah satu solusi dalam mengintegrasikan lingkungan dalam pembangunan ekonomi berkelanjutan. Penelitian Ciocoiu (2011) menemukan bahwa ekonomi hijau dapat menawarkan solusi dalam jangka panjang. Salah satu tanggapan terhadap tantangan perubahan iklim dan memastikan berkelanjutan pembangunan adalah Pengetahuan Ekonomi Hijau. Pada umumnya, ekonomi hijau bisa menjadi jawaban untuk perubahan dalam meramalkan iklim dan pemanasan global, karena mempromosikan ekonomi dan sosial pengembangan yang berkelanjutan. Pop et al. (2011) menemukan bahwa aspek sosial ekonomi hijau dalam mengatasi perubahan iklim memerlukan cara kerja baru yang akan mempengaruhi seluruh masyarakat. Pelatihan keterampilan dan pendidikan telah mungkin kurang mendapat perhatian to date dari pada faktor-faktor lain dalam kepentingan mereka untuk mencapai cepat transisi ke masyarakat rendah karbon. Jenis kebijakan yang akan mempromosikan ekonomi hijau termasuk langkah-langkah dirancang untuk meningkatkan kesadaran masyarakat tentang manfaat kebijakan hijau. 


\section{KESIMPULAN}

Kesimpulan dari penelitian ini adalah potensi ekonomi peternak sapi perah telah memberikan pengaruh signifikan sebesar 2,657 terhadap pembangunan ekonomi hijau. Hal ini menunjukkan bahwa potensi ekonomi peternak sapi perah merupakan faktor yang menentukan pembangunan ekonomi hijau di Kabupaten Pasuruan. Saran dalam penelitian ini adalah perlu dilakukan kajian penelitian tentang strategi peningkatan potensi ekonomi peternak sapi perah di Kabupaten Pasuruan.

\section{DAFTAR PUSTAKA}

Babonea, A. M., \& Joia, R. M. (2012). Transition to a green economy-a challenge and a solution for the world economy in multiple crisis context. Theoretical and Applied Economics, 10(10), 105.

BPS. 2013. Statistik Indonesia (2013). Badan Pusat Statistik. Jakarta.

Caprotti, F., \& Bailey, I. (2014). Making sense of the green economy. Geografiska Annaler: Series B, Human Geography, 96(3), 195-200.

Ciocoiu, C. N. (2011). Integrating digital economy and green economy: opportunities for sustainable development. Theoretical and Empirical Researches in Urban Management, 6(1), 33.

Green, D. D., \& McCann, J. (2011). Benchmarking a leadership model for the green economy. Benchmarking: An International Journal, 18(3), 445-465.

Nemon, H. (2000). Community economic development in distressed urban neighborhoods: A case study of the Philadelphia Empowerment Zone.

Pop, O., Dina, G. C., \& Martin, C. (2011). Promoting the corporate social responsibility for a green economy and innovative jobs. ProcediaSocial and Behavioral Sciences, 15, 1020-1023.

Priyono dan Priyanti, A (2015). Penguatan kelembagaan koperasi susu melalui pendekatan pengembangan kawasan peternakan nasional. Wartazoa, 25(2), 085-094.

Sutikno, B. dan Batoro, D. (2016). Potensi ekonomi dan peran koperasi susu dalam pembangunan masyarakat lokal. Jurnal agromix, 9(1).

Woolcock, M. and Narayan, D. (2000). Social capital: Implications for development theory, research, and policy. The world bank research observer, 15(2), 225-249. 